\title{
ANALISIS PENGARUH KARAKTERISTIK PEMDA, INDEKS PEMBANGUNAN MANUSIA, DAN KUALITAS HASIL AUDIT TERHADAP TINGKAT PENGUNGKAPAN LKPD
}

\author{
Penulis: \\ Usrotun Najah ${ }^{1}$ \\ usrotunnajah28@gmail.com \\ Dra. Atiek Sri Purwati, M.Si., Ak \\ aisyaatiek@yahoo.com
}

\begin{abstract}
The purpose of this study is aimed to determine the influence of the characteristics of region governments. The characteristics includes the regional government's wealth; balance funds; and the level of regional financial independence, the Human Development Index, and the BPK audit quality results which includes findings; deviation level; and audit opinion toward the level of disclosure in local government financial statements. The populations in this study are all the Local Government Financial Reports of regencies and cities in Central and East Java. The number of samples in this study were 130 Local Government Financial Statements. The result of this study shows that: Regional Government Wealth and Regional Financial Independence Ratios significantly influences the Local Government Financial Statement disclosure level, while Intergovernmental Revenue; The Human Development Index; Audit Findings; Audit Deviation Levels; and Audit Opinions did not significantly influences the Local Government Financial Statement disclosure level.
\end{abstract}

Keywords: disclosure level, characteristics of region governments, IPM, audit result quality, Local Government Financial Statement.

\section{PENDAHULUAN}

Indonesia telah menjalankan sistem pemerintahan desentralisasi sejak era reformasi atau sejak 19 tahun yang lalu yang dimulai sejak ditetapkannya Undang-Undang Nomor 22 Tahun 1999 mengenai pemerintah daerah, dilanjutkan dengan disahkannya Undang-Undang Nomor 25 Tahun 1999 mengenai perimbangan keuangan antara pemerintah pusat dan daerah. Undang-undang tersebut mengalami revisi menjadi Undang-Undang Nomor 32 Tahun 2004 mengenai kewenangan otonomi daerah. Selain memberikan kewenangan atas otonomi daerah, pemerintah juga terus berusaha mengimbangi dengan mewujudkan tata kelola yang baik (good public governance), yaitu dengan mewajibkan setiap entitas pelaporan menyusun

\footnotetext{
${ }^{1}$ Universitas Jenderal Soedirman
} 
laporan keuangan dan laporan kinerja sebagai pertanggungjawaban atas pelaksanaaan APBN/APBD.

Kerangka Konseptual Standar Akuntansi Pemerintahan menyebutkan salah satu prinsip akuntansi adalah pengungkapan lengkap (full disclosure), di mana laporan keuangan menyajikan secara lengkap informasi-informasi yang berguna bagi pengguna laporan keuangan baik pada lembar muka laporan keuangan ataupun pada Catatan atas Laporan Keuangan (CaLK) (Febriyani Syafitri, 2012), namun pada kenyataannya masih ada laporan keuangan pemerintah daerah yang belum sepenuhnya mengungkapkan seluruh informasi secara lengkap. Informasi tersebut ditandai dengan adanya data yang dikeluarkan oleh Badan Pemeriksa Keuangan (BPK) mengenai opini atas laporan keuangan dari pemerintah daerah yang belum mengungkapkan informasi keuangan daerah tersebut secara lengkap.

Penelitian yang telah dilakukan untuk mengukur tingkat kepatuhan pengungkapan wajib Laporan Keuangan Pemerintah Daerah (LKPD) terhadap standar akuntansi pemerintahan masih tebilang rendah (Syafitri, 2012). Ikhtisar Hasil Pemeriksaan Semester II Tahun 2015 mengungkap masih terdapat 35 Pemda yang terlambat menyampaikan laporan keuangannya terhadap BPK, namun dalam kurun waktu 5 tahun terakhir atau sejak tahun 2012 hingga tahun 2016 menunjukkan tingkat pengungkapan laporan keuangan terus mengalami tren kenaikan. Berikut tabel 1.1 yang menunjukkan perkembangan opini atas Laporan Keuangan Pemeintah Daerah (LKPD) kabupaten/kota dari tahun 2012 hingga tahun 2016.

Tabel 1. Perkembangan Opini LKPD Tahun 2012-2016

LKPD Opini Jumlah

\begin{tabular}{cccccccccc}
\hline \multirow{2}{*}{ LKPD } & \multicolumn{7}{c}{ Opini } & \multirow{2}{*}{ Jumlah } \\
\cline { 2 - 9 } & WTP & $\%$ & WDP & $\%$ & TW & $\%$ & TMP & $\%$ & \\
\hline 2012 & 120 & $23 \%$ & 319 & $61 \%$ & 6 & $1 \%$ & 78 & $15 \%$ & 523 \\
\hline 2013 & 156 & $30 \%$ & 310 & $59 \%$ & 11 & $2 \%$ & 47 & $9 \%$ & 524 \\
\hline 2014 & 252 & $47 \%$ & 247 & $46 \%$ & 5 & $1 \%$ & 35 & $6 \%$ & 539 \\
\hline 2015 & 313 & $58 \%$ & 194 & $36 \%$ & 4 & $1 \%$ & 31 & $5 \%$ & 542 \\
\hline 2016 & 375 & $70 \%$ & 139 & $26 \%$ & 0 & $0 \%$ & 23 & $4 \%$ & 537 \\
\hline
\end{tabular}

Sumber: BPK RI 2017 
Meskipun dalam kurun waktu 5 tahun terakhir, Pemda telah menunjukkan peningkatan dalam pengungkapan LKPD, namun potensi kerugian yang dihadapi masih terbilang tinggi. Berikut tabel 1.2 yang menunjukkan temuan ketidakpatuhan atas ketentuan perundangundangan pada pemeriksaan keuangan semester I tahun 2017.

Tabel 2. Jumlah dan Nilai Permasalahan Ketidakpatuhan terhadap Ketentuan Peraturan Perundang-undangan pada Pemeriksaan LKPD Tahun 2016

\begin{tabular}{|c|c|c|c|}
\hline \multirow[b]{2}{*}{ No. } & \multirow[b]{2}{*}{ Sub Kelompok Temuan } & \multicolumn{2}{|c|}{ Permasalahan } \\
\hline & & $\begin{array}{l}\text { Jumlah } \\
\text { Kasus }\end{array}$ & $\begin{array}{l}\text { Nilai (dalam } \\
\text { miliaran rupiah) }\end{array}$ \\
\hline \multicolumn{4}{|c|}{$\begin{array}{l}\text { Ketidakpatuhan terhadap ketentuan peraturan perundang-undangan yang } \\
\text { mengakibatkan: }\end{array}$} \\
\hline & Kerugian Negara/Daerah & 2.525 & $1.130,17$ \\
\hline & $\begin{array}{l}\text { Potensi kerugian } \\
\text { Negara/Daerah }\end{array}$ & 413 & 419,60 \\
\hline 3. & $\begin{array}{l}\text { Kekurangan penerimaan } \\
\text { Negara/Daerah }\end{array}$ & 846 & 537,72 \\
\hline & Total 1 (berdampak finansial) & 3.784 & $2.087,49$ \\
\hline & Penyimpangan Administrasi & 2.331 & - \\
\hline & otal 2 (tidak berdampak finansial) & 2.331 & - \\
\hline & Total $1+$ Total 2 & 6.115 & $2.087,49$ \\
\hline & $\begin{array}{r}\text { Penyetoran uang ke kas negara } \\
\text { pen }\end{array}$ & $\begin{array}{l}\text { erah atau } \\
\text { ahan aset }\end{array}$ & 388,19 \\
\hline
\end{tabular}

Sumber: BPK RI 2017

Terdapat beberapa penelitian yang menganalisis faktor-faktor apa saja yang mempengaruhi tingkat pengungkapan LKPD. Patricia A. Patrick (2007), Nur Lailatul Khasanah (2014), dan Maulana (2015) dalam penelitiannya menyatakan bahwa size atau ukuran pemerintah daerah memiliki hubungan positif dan signifikan terhadap tingkat pengungkapan laporan keuangan, namun ditolak oleh Lesmana (2010), Yulianingtyas (2010), Syafitri (2012), Heri Atapson V Girsang (2015), serta Akhmad Prihardjanto dan Yusniar Yulianana Wardani (2016). Intergovernmental Revenue terhadap tingkat pengungkapan LKPD. Syafitri (2012) dan Hilmi (2012) melakukan penelitian yang menunjukkan adanya hubungan positif dan signifikan antara Intergovernmental Revenue terhadap tingkat pengungkapan LKPD, namun penelitian serupa menunjukkan hasil yang berbeda, seperti penelitian yang dilakukan oleh Khasanah (2014), Maulana (2015), Girsang (2015), Prihardjanto dan Wardani (2016), serta Lilis 
Setyowati (2016). Kemandirian pemerintah daerah merupakan salah satu faktor yang mempengaruhi tingkat pengungkapan LKPD. Penelitian sebelumnya dilakukan oleh Lesmana (2010) menemukan adanya hubungan positif dan signifikan antara kemandirian daerah dengan tingkat pengungkapan LKPD, namun, Syafitri (2012), Maulana (2015), Girsang (2015), dan Hendriyani (2015) menemukan hasil yang berbeda. Indeks Pembangunan Manusia (IPM) merupakan angka yang menunjukkan kualitas hidup manusia. Setyowati (2016) melakukan penelitian mengenai determinan apa saja yang mempengaruhi pengungkapan LKPD, hasilnya IPM memiliki pengaruh negatif terhadap pengungkapan LKPD, hal tersebut mendorong untuk diteliti lebih lanjut pengaruh IPM terhadap tingkat pengungkapan LKPD. Kualitas hasil audit yang terdiri atas temuan dan tingkat penyimpangan audit. Liestiani (2008) dalam penelitiannya menyatakan adanya pengaruh positif dan signifikan antara temuan audit dengan tingkat pengungkapan LKPD, namun ditolak oleh Andriani (2012), Maulana (2015), Hendriyani (2015), serta Prihardjanto dan Wardani (2016). Liestiani (2008) juga menyebutkan adanya hubungan positif dan signifikan antara tingkat penyimpangan audit terhadap pengungkapan LKPD yang didukung dengan penelitian yang dilakukan oleh Hilmi (2012), namun, hasil penelitian yang dilakukan oleh Prihardjanto dan Wardani (2016) menunjukkan hasil sebaliknya. Opini audit merupakan opini yang diberikan oleh auditor BPK setelah melakukan proses audit. Penelitian yang dilakukan oleh Andriani (2012) serta Prihardjanto dan Wardani (2016) sama-sama menunjukkan bahwa opini audit memili pengaruh positi dan signifikan terhadap tingkat pengungkapan laporan keuangan yang dilakukan oleh pemda.

Penelitian ini bertujuan untuk mengetahui pengaruh karakteristik Pemda diantaranya kekayaan Pemda; intergovernmental revenue; serta tingkat kemandirian keuangan daerah, Indeks Pembangunan Manusia, serta kualitas hasil audit BPK yang meliputi temuan; tingkat penyimpangan; serta opini audit terhadap tingkat pengungkapan dalam laporan keuangan pemerintah daerah. 


\section{LANDASAN TEORI DAN PENGEMBANGAN HIPOTESIS}

\section{A. Landasan Teori}

\section{Teori Stewardship}

Donaldson dan Davis (1997) dalam Raharjo (2007) menyatakan teori stewardship memiliki akar psikologi dan sosiologi yang dirancang untuk menjelaskan situasi di mana manajer sebagai steward dan bertindak sesuai kepentingan pemilik atau principal. Teori stewardship mempunyai dasar psikologi dan sosiologi yang telah didisain di mana steward (penerima tugas) termotivasi untuk bertindak sesuai dengan keinginan principal (pemberi tugas) dan tidak akan meninggalkan organisasi untuk mencapai tujuan organisasi tersebut. Dalam lingkup sektor publik, Steward merupakan pemerintah daerah yang mana berkewajiban untuk melakukan pengungkapan dengan menyusun laporan keuangan sebagai bentuk pertanggung jawaban atas berbagai sumber daya yang digunakan dalam menjalankan kegiatan operasionalnya, sedangkan principal merupakan masyarakat yang mendiami daerah tersebut. Laporan keuangan pemerintah daerah ini juga merupakan salah satu wujud pelaksanaan prinsip Good Public Governance.

\section{B. Pengembangan Hipotesis}

Kekayaan pemda dalam penelitian ini diproksikan dengan total aset yang merupakan sumber daya yang digunakan pemerintah daerah untuk melakukan kegiatan operasionalnya. Menurut Yulianingtyas (2010) dalam penelitiannya, menyebutkan bahwa organisasi yang besar cenderung memiliki atau menerapkan aturan dan ketentuan yang lebih banyak dibanding organisasi kecil. Hal tersebut terjadi karena semakin besar ukuran atau kekayaan organisasi, semakin besar pula kompleksitas dalam mengelola dan menjaga asetnya. Kompleksitas tersebut dapat menarik perhatian publik dan menjadikan public demand atas informasi yang lebih tinggi dibanding organisasi dengan kompleksitas rendah atau kekayaan yang kecil. Hal tersebut sejalan dengan teori stewardship, di mana dalam konteks organisasi pemerintahan pihak principal dalam hal ini publik menuntut pemerintah sebagai steward untuk 
menjalankan tugas pemerintahan dan mempertanggungjawabkannya melalui pengungkapan pada LKPD. Dari uraian tersebut, maka hipotesis penelitian ini adalah:

\section{$\mathrm{H}_{1}$ : Kekayaan pemerintah daerah berpengaruh signifikan terhadap tingkat pengungkapan LKPD.}

Intergovernmental revenue atau di Indonesia dikenal dengan dana perimbangan adalah dana yang bersumber dari pendapatan APBN yang dialokasikan kepada daerah dalam rangka pelaksanaan desentralisasi (Syafitri, 2012). Dengan adanya dana perimbangan, pemda didorong untuk meningkatkan transparansi atas dana tersebut, sehingga dapat meningkatkan kepercayaan pemerintah pusat serta menunjukkan kepatuhan terhadap peraturan yang berlaku. Selain itu, pemerintah pusat juga melakukan pengawasan atas dana perimbangan melalui Badan Pengawasan Keuangan dan Pembangunan (BPKP) yang melaksanakan fungsi pengawasan keuangan internal pemda dan Badan Pemeriksa Keuangan (BPK) yang melakukan fungsi pemeriksaan eksternal pemda. Dari uraian di atas, hipotesis dalam penelitian ini adalah:

\section{$\mathrm{H}_{2}$ : Intergovernmental Revenue berpengaruh secara signifikan terhadap tingkat pengungkapan LKPD.}

Rasio kemandirian keuangan daerah bertujuan untuk mengukur kemampuan suatu pemerintah daerah dalam menjalankan kegiatan operasionalnya tanpa adanya dana perimbangan dari pemerintah pusat (Dwiranda, 2008 dalam Syafitri, 2012). Kemandirian pemerintah daerah dapat dilihat dari perbandingan antara Pendapatan Asli Daerah (PAD) dengan total penapatan daerah (Imawan, 2014 dalam Maulana, 2015). Rasio ini dapat menggambarkan tingkat partisipasi masyarakat dalam membayar pajak dan retribusi sebagai PAD. Semakin tinggi rasio ini menunjukkan semakin tinggi pula partisipasi masyarakat dalam pembiayaan kegiatan operasional pemerintah daerah. Hal tersebut menimbulkan semakin tinggi pula tuntutan transparansi atas pengungkapan pada laporan pertanggungjawaban pemerintah daerah. Dari uraian di atas, maka hipotesis penelitian ini adalah: 


\section{$\mathrm{H}_{3}$ : $\quad$ Rasio Kemandirian Keuangan Daerah berpengaruh secara signifikan terhadap tingkat pengungkapan LKPD.}

Negara-negara yang memiliki IPM yang baik cenderung memiliki tata kelola pemerintahan yang baik pula. Semakin baik pertumbuhan IPM maka semakin baik pula pemerintahan yang dihasilkan (Ramachandran, 2002 dalam Setyowati, 2016). Tata kelola pemerintahan yang baik mensyaratkan adanya keberadaan masyarakat yang tingkat pembangunannya baik pula. Dalam penelitiannya juga dijelaskan bahwa semakin tinggi pembangunan masyarakat, maka semakin beragam keinginan masyarakat yang ingin dipenuhi, yang akhirnya akan menimbulkan tuntutan kepada pemerintah untuk melakukan pengungkapan yang lebih detail atau lebih luas atas laporan pertanggungjawaban yang disusun pemerintah daerah. Dari uraian di atas, maka hipotesis dalam penelitian ini adalah:

\section{$\mathrm{H}_{4}$ : Indeks Pembangunan Manusia (IPM) berpengaruh secara signifikan terhadap tingkat pengungkapan LKPD.}

Maulana (2015) menjelaskan temuan audit BPK-RI merupakan kasus-kasus yang ditemukan BPK atas laporan keuangan pemerintah daerah atas pelanggaran yang dilakukan suatu daerah terhadap efektifitas pengendalian intern maupun tingkat kepatuhan terhadap ketentuan perundang-undangan yang berlaku. Dengan adanya temuan kasus tersebut, BPK akan mendorong adanya peningkatan pengungkapan dan koreksi sebagai upaya koreksi dan perbaikan untuk perubahan dimasa yang akan datang atas temuan audit yang dilakukan pemda. Pengungkapan yang dilakukan secara luas sebagai upaya perbaikan dan koreksi atas temuan kasus audit, menunjukkan pada publik adanya perbaikan kualitas laporan keuangan yang dilakukan pemda atas saran dari BPK. Apabila jumlah temuan audit pada periode sebelumnya tinggi, maka periode selanjutnya akan mengalami perbaikan atau peningkatan pengungkapan LKPD. Atas uraian yang telah dipaparkan, maka hipotesis dalam penelitian ini adalah: 


\section{$\mathrm{H}_{5}$ : Temuan Audit tahun lalu berpengaruh secara signifikan terhadap tingkat pengungkapan LKPD.}

Sama dengan temuan audit, jika nilai dari penyimpangan audit yang didapat pada periode sebelumnya bernilai besar, maka diharapkan pada periode selanjutnya terdapat perubahan yang lebih baik oleh pemda dalam mengurangi penyimpangan tersebut sehingga berakibat pada pengungkapan atas laporan keuangan yang dihasilkan pemda menjadi lebih baik. Selain itu, jika nilai tingkat penyimpangan audit yang didapat pada periode sebelumnya besar, maka dapat mengindikasikan bahwa pengungkapan pada laporan keuangan pada tahun tersebut juga rendah. Atas uraian yang telah dipaparkan, maka hipotesis dalam penelitian ini adalah:

\section{$\mathrm{H}_{6}$ : Tingkat Penyimpangan Audit tahun lalu berpengaruh secara signifikan terhadap tingkat pengungkapan LKPD.}

Andriani (2012) mengutip dari penjelasan pasal 16 Undang-Undang No. 15 Tahun 2004 menyebutkan bahwa kewajaran informasi dalam laporan keuangan yang dinyatakan melalui Opini Auditor, didasarkan pada 4 poin, yaitu: (a) kesesuaian dengan standar akuntansi pemerintahan; (b) kecukupan pengungkapan (adequate disclosure); (c) kepatuhan terhadap peraturan perundang-undangan; serta (d) efektivitas sistem pengendalian internal. Pada poin kedua, yaitu kecukupan pengungkapan merupakan salah satu bagian yang menentukan opini audit, karena informasi-informasi penting terkait dengan pengelolaan keuangan pemda harus diungkap minimal mencakup pengungkapan wajib yang telah diatur di SAP. Hal tersebut dilakukan supaya tidak menyesatkan masyarakat sebagai pengguna laporan keuangan pemda. Semakin tinggi opini audit yang yang diberikan auditor, maka akan menunjukkan semakin tinggi pula kualitas audit yang mengindikasikan tingkat pengungkapan laporan keuangan pemda yang tinggi pula, dan sebaliknya. Atas uraian yang telah dipaparkan, maka hipotesis dalam penelitian ini adalah: 
$\mathrm{H}_{7}$ : Opini Audit tahun lalu berpengaruh secara signifikan terhadap tingkat pengungkapan LKPD.

\section{METODE PENELITIAN}

\section{Populasi, sampel, dan Teknik Pengambilan Sampel}

Populasi dalam penelitian ini adalah seluruh laporan keuangan pemda kabupaten/kota di Jawa Tengah dan Jawa Timur Tahun Anggaran 2015-2016 yang berjumlah 146 LKPD. Pemilihan sampel yang digunakan dalam penelitian ini adalah teknik purposive sampling, yaitu penentuan sampel penelitian yang dilakukan berdasarkan kriteria-kriteria yang dibuat oleh peneliti (Sekaran, 2010). Kriteria-kriteria atas sampel yang digunakan dalam penelitian ini adalah sebagai berikut: (1) Laporan Keuangan Pemerintah Daerah (LKPD) kabupaten/kota yang telah di audit oleh BPK RI, dan yang telah mendapatkan opini Wajar Tanpa Pengecualian (WTP) dan WDP (Wajar Dengan Pengecualian) pada periode 2015-2016. (2) Memiliki komponen laporan keuangan pemda, diantaranya Laporan Realisasi Anggara (LRA), Neraca, Laporan Arus Kas, dan Catatan atas Laporan Keuangan. (3) Memiliki data lengkap yang mencakup seluruh variabel.

\section{Definisi Operasional dan Pengukuran Variabel}

\section{a. Variabel Dependen}

Variabel dependen yang digunakan dalam penelitian ini adalah tingkat pengungkapan Laporan Keuangan Pemerintah Daerah yang diukur dengan cara scoring jumlah butir pengungkapan laporan kuangan berdasarkan Standar Akuntansi Pemerintahan (SAP) yang diungkapkan oleh pemerintah daerah, yaitu yang tercantum dalam PSAP Nomor 05 sampai dengan PSAP Nomor 09. 


\section{b. Variabel Independen}

\section{1) Kekayaan Pemerintah Daerah}

Variabel kekayaan pemerintah daerah pada penelitian ini diproksikan dengan total aset dari pemerintah daerah. Total aset berasal dari neraca, diantaranya aset lancar dan aset non lancar, di mana total aset dinyatakan dalam satuan rupiah. Total aset pemerintah terdiri atas: Kas pada Kas Daerah, Investasi Jangka Panjang, Aset Tetap, Dana Cadangan dan Aset lainnya (Maulana, 2015).

\section{2) Intergovernmental Revenue}

Intergovernmental revenue atau biasa disebut dengan pendapatan transfer adalah jenis pendapatan daerah yang berasal dari transfer pemerintah pusat dan atau pemerintah provinsi yang dinyatakan dalam satuan rupiah. Data mengenai jumlah pendapatan transfer dapat diperoleh dari Laporan Realisasi Anggaran (LRA). Proksi dari variabel ini adalah Total Pendapatan Transfer dibanding Total Pendapatan Daerah.

\section{3) Rasio Kemandirian Keuangan Daerah}

Rasio kemandirian keuangan daerah merupakan tingkat kemampuan pemeritnah daerah dalam membiayai sendiri kegiatan operasional pemerintahan yang terkait dengan pembangunan serta pelayanan kepada masyarakat yang telah membayar pajak dan retribusi sebagai sumber pendapatan yang diperlukan pemda. Variabel ini diukur dengan cara membandingkan Pendapatan Asli Daerah dengan Total Pendapatan Daerah.

\section{4) Indeks Pembangunan Manusia}

Indeks pembangunan manusia merupakan salah satu alat ukur yang dapat menunjukkan tingkat kemajuan yang dicapai suatu masyarakat. Salah satu syarat dalam tata kelola pemerintahan yang baik yaitu adanya masyarakat dengan tingkat pembangunan yang baik pula. Semakin baik pembangunan masyarakat, semakin 
beragam pula keinginan yang ingin dipenuhi, salah satunya tuntutan akan keinginan pengungkapan laporan keuangan pemda yang lebih rinci. Variabel IPM dinyatakan dalam satuan presentase (Setyowati, 2016).

\section{5) Temuan Audit}

Kasus-kasus yang ditemukan BPK atas laporan keuangan pemda atas pelanggaran yang dilakukan suatu daerah terhadap ketentuan pengendalian intern maupun ketentuan perundang-undangan merupakan temuan audit BPK. Temuan audit yang digunakan dalam penelitian ini adalah jumlah temuan audit pemeriksaan BPK RI atas kepatuhan peraturan perundang-undangan sebagai proksi dalam mengukur temuan audit yang berdasarkan temuan audit pada laporan keuangan pemda.

\section{6) Tingkat Penyimpangan Audit}

Tingkat penyimpangan yang ditemukan dalam audit merupakan perbandingan antara nominal temuan kepatuhan terhadap peraturan perundang-undangan dengan total belanja daerah. Tingkat penyimpangan temuan audit menggunakan jumlah nominal kasus-kasus yang berdampak kerugian daerah, potensi kerugian darah, kekurangan penerimaan, tidak hemat, efektif dan efisien.

\section{7) Opini Audit}

Opini audit merupakan penilaian diberikan oleh auditor BPK atas hasil proses pemeriksaan (auditing) terhadap laporan keuangan pemda. Data opini audit pada penelitian ini menggunakan data pada tahun sebelumnya. Pengukuran untuk opini audit Wajar Tanpa Pengecualian (WTP) dinilai 3, Wajar Tanpa Pengecualian Dengan Paragraf Penjelas (WTP DPP) dinilai 2, serta Wajar Dengan Pengecualian (WDP) dinilai 1.

\section{Persamaan Regresi}

Persamaan regresi linier berganda dalam penelitian ini dirumuskan sebagai berikut: 


$$
Y=\alpha+\beta_{1} X_{1}+\beta_{2} X_{2}+\beta_{3} X_{3} \beta_{4} X_{4} \beta_{5} X_{5}+\beta_{6} X_{6}+\beta_{7} X_{7}+e
$$

\section{HASIL PENELITIAN DAN PEMBAHASAN}

\section{Seleksi Sampel}

Data yang digunakan dalam penelitian ini berupa data sekunder yang merupakan laporan keuangan pemda kabupaten maupun kota di Jawa Tengah dan Jawa Timur dengan tahun anggaran 2015-2016 yang telah diaudit oleh BPK. Berikut merupakan tabel yang menggambarkan proses pengambilan sampel untuk pemerintah daerah pada tahun 20152016.

Tabel 3. Seleksi Sampel Penelitian

\begin{tabular}{lr}
\hline \multicolumn{1}{c}{ Keterangan } & \multicolumn{1}{c}{ Tahun } \\
& $2015-2016$ \\
\hline Jumlah LKPD & 146 \\
Jumlah LKPD yang corrupt & $(3)$ \\
Jumlah LKPD tidak memenuhi kriteria & $(13)$ \\
\hline Jumlah sampel LKPD kabupaten/kota se-Jawa Tengah & 130 \\
dan Jawa Timur (2 tahun anggaran) & \\
\hline
\end{tabular}

Tabel di atas memberi informasi bahwa, terdapat 73 pemerintah daerah kabupaten/kota di Jawa Tengah dan Jawa Timur atau dengan kata lain terdapat 146 LKPD (2 tahun anggaran), namun, data yang diperoleh hanya berjumlah 143 LKPD. Tiga (3) LKPD berasal dari Jawa Timur corrupt dan tidak dapat digunakan, yaitu LKPD kabupaten Bangkalan, Jombang, dan kota Madiun. Dari 143 sampel LKPD ini, kemudian dilakukan seleksi berupa kriteria purposive sampling yang telah ditentukan. Terdapat beberapa pemda yang masih belum menyajikan komponen laporan keuangan secara lengkap, diantaranya pemkab Sragen, Tegal, serta pemkot Pekalongan dan Salatiga. Selain itu, neraca pemkab Sukoharjo terdapat keterangan unaudited atau belum diaudit sehingga tidak lolos kriteria penentuan sampel penelitian. Atas dasar alasan tersebut, maka ditetapkanlah sampel penelitian berjumlah 65 kabupaten/kota atau 130 laporan keuangan pemda.

\section{Statistik Deskriptif}


Terdapat beberapa informasi dalam analisis statistik deskriptif diantaranya untuk mengetahui besarnya nilai minimum, maksimum, rata-rata, serta standar deviasi dari masingmasing data variabel. Nilai minimum menjelaskan berapa nilai terrendah dari masing-masing data variabel, sedangkan nilai maksimum merupakan kebalikan dari minimum yaitu nilai terbesar yang dimiliki oleh data variabel. Statistik deskriptif juga menyediakan informasi mengenai nilai rata-rata masing-masing data variabel. Berikut hasil analisis statistik deskriptif dalam tabel 4 .

Tabel 4. Hasil Analisis Statistik Deskriptif

\begin{tabular}{lrrrr}
\hline Variabel & Min & \multicolumn{1}{l}{ Max } & Mean & Std. Deviasi \\
\hline DISC & 64,15 & 101,13 & 83,1074 & 7,3037 \\
KEKAYAAN & 55 & 67 & 57,68 & 1,602 \\
IREV & 0,4935 & 1,7727 & 1,3859 & 0,245 \\
RKKD & 0,1611 & 0,7225 & 0,32 & 0,121 \\
IPM & 117 & 161 & 139,21 & 9,502 \\
TEMUAN & 0 & 31 & 7,22 & 6,492 \\
TPA & 0 & 0,8652 & 0,06846 & 0,146 \\
OPINI & 2 & 6 & 3,94 & 1,467 \\
\hline
\end{tabular}

Tabel analisis statistik deskriptif di atas menunjukkan bahwa, nilai rerata pengungkapan wajib dalam laporan keuangan pemda adalah 83,1074 atau sebesar 73,04\%, hasil tersebut menggambarkan bahwa kepatuhan pengungkapan wajib sesuai dengan SAP sudah cukup baik, sebab hampir 50\% dari total sampel sebanyak 130 LKPD telah melebihi nilai rerata pengungkapan wajib (lebih dari 83,1074). Tingkat pengungkapan minimum diperoleh pemkab Blora sebesar 64,15, sedangkan pengungkapan maksimum diperoleh pemkab Pasuruan sebesar 101,13.

Nilai rerata kekayaan pemda adalah 57,68 atau senilai Rp8.033.148.761.471,99. Kekayaan atau total aset terbesar diperoleh oleh Pemkot Surabaya yaitu 67 atau senilai Rp76.357.440.574.354,40, sedangkan total aset terkecil diperoleh Pemkot Batu yaitu 55 atau senilai Rp2.888.579.948.758,45. Nilai rerata intergovernmental revenue sebesar 1.3859 atau $24,5 \%$. Nilai maksimum dari intergovernmental revenue diperoleh pemkab Kebumen dengan nilai rasio 1,7727 , sedangkan nilai rasio minimum diperoleh pemkot Surabaya senilai 0,4935 . Nilai rerata rasio kemandirian keuangan daerah dalam 2 tahun anggaran ini sebesar 0,32. 
Nilai rasio terendah diperoleh pemerintah daerah kabupaten Sampang sebesar 0,1611. Nilai rasio tertinggi senilai 0.7225 diperoleh pemerintah Kota Surabaya dalam 2 tahun anggaran. Nilai rata-rata Indeks Pembangunan Manusia di Jawa Tengah dan Jawa Timur pada tahun 2015-2016 sebesar 139,21. Nilai IPM terendah sebesar 117 diperoleh daerah kabupaten Sampang. Berbeda dengan kabupaten Sampang, Kota Semarang mendapatkan nilai IPM tahun 2015-2016 terbesar dengan nilai 161 . Nilai rerata temuan audit sebesar 7,22 atau 7 (dibulatkan) kasus temuan audit di Jawa Tengah dan Jawa Timur. Jumlah temuan audit terendah adalah 0 yang diperoleh oleh 15 pemerintah daerah. Jumlah temuan audit tertinggi diperoleh pemda kabupaten Karanganyar sejumlah 31 temuan. Nilai rerata tingkat penyimpangan yang ditemukan dalam audit yang terjadi pada setiap daerah adalah 0,06846. Selama tahun 2014-2015, tingkat tertinggi penyimpangan yang ditemukan sebesar 0,8652 di pemerintah kota Batu, sedangkan beberapa pemda justru mendapatkan tingkat penyimpangan terendah senilai 0,00 . Nilai rerata opini audit tahun sebelumnya (tahun 20142015) sebesar 3,94 yang jika di rata-rata (dibagi 2) hampir mencapai poin 2 yaitu opini WTP DDP. Terdapat 7 dari total 65 daerah yang mendapat skor opini maksimal yaitu 6 (opini WTP dalam 2 tahun), namun sebanyak 21 daerah yang mendapat skor opini terendah yaitu 2 (opini WDP dalam 2 tahun).

\section{Pengujian Hipotesis dan Pembahasan}

Analisis regresi linier berganda dilakukan dengan alat uji SPSS.

Tabel 5. Hasil Regresi Linier Berganda 
86 Jurnal Kajian Ekonomi \& Keuangan Daerah, Volume 5, Nomor 1, Agustus 2019: 70-88

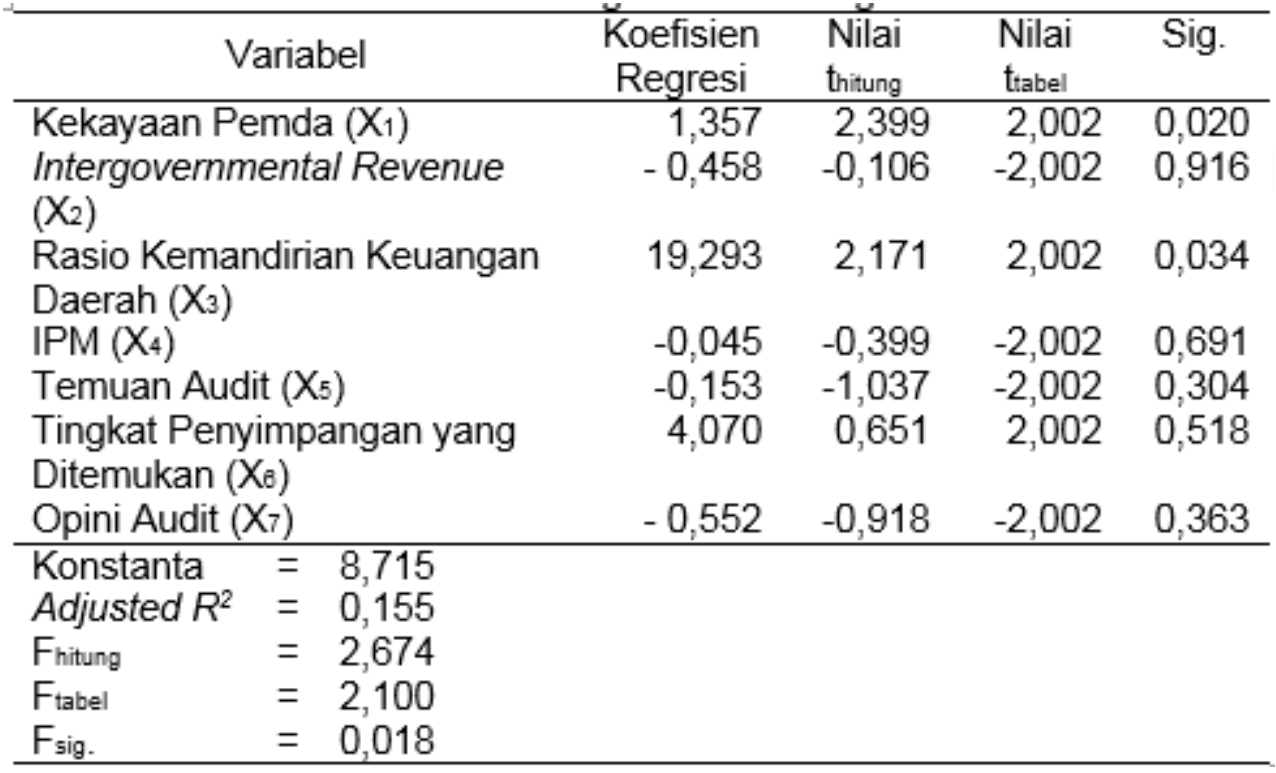

Tabel 5 menunjukkan bahwa nilai Adjusted $R$ Square $\left(R^{2}\right)$ sebesar 0,155 , sehingga dapat disimpulkan bahwa 15,5\% variabel terikat atau tingkat pengungkapan LKPD dapat dijelaskan oleh variabel bebas, diantaranya variabel Kekayaan Pemda, Intergovernmental Revenue, Rasio Kemandirian Keuangan Daerah, Indeks Pembangunan Manusia, Temuan Audit, Tingkat Penyimpangan yang Ditemukan, dan Opini Audit, sedangkan sisanya sebanyak $84,5 \%$ dijelaskan oleh faktor lain. nilai $F_{\text {hitung }}$ sebesar 2,674 dengan probabilitas 0,018 . Nilai $F_{\text {hitung }}$ sebesar 2,674 melebihi nilai $F_{\text {tabel }}$ sebesar 2,180 serta nilai probabilitas sebesar 0,018 atau kurang dari $5 \%$ (probabilitas $<0,05$ ), sehingga dapat disimpulkan bahwa model regresi dapat digunakan untuk memprediksi tingkat pengungkapan LKPD.

Hasil regresi di atas juga menunjukkan hanya 2 variabel independen yang berpengaruh signifikan terhadap variabel dependen, yaitu kekayaan dan rasio kemandirian keuangan pemerintah daerah, sementara variabel independen lainnya yaitu intergovernmental revenue, IPM, temuan, tingkat penyimpangan dan opini audit terbukti tidak mempengaruhi tingkat pengungkapan LKPD secara signifikan.

Kekayaan pemda berpengaruh signifikan terhadap tingkat pengungkapan LKPD, ini menunjukkan peran aktif dari masyarakat dengan taat melakukan setor pajak daerah, retribusi, dan lain-lain dapat mendorong Pemda dalam melakukan pengungkapan yang sesuai standar. 
Maulana (2015) juga berpendapat pemerintah daerah yang memiliki total aset atau kekayaan yang besar dituntut untuk melakukan transparansi atas pengelolaan keuangannya sebagai bentuk akuntabilitas publik dengan melakukan pengungkapan informasi yang lebih banyak atau lengkap dalam LKPD. Hasil ini selaras dengan Patrick (2007), Liestiani (2008), Syafitri (2012), Hilmi (2012), serta Maulana (2015), namun hasil ini juga bertentangan dengan Lesmana (2010), Yulianingtyas (2010), Khasanah (2014), Girsang (2015), Prihardjanto dan Wardani (2016), serta Setyowati (2016).

Pengujian hipotesis di atas menyatakan bahwa intergovernmental Revenue tidak berpengaruh signifikan terhadap tingkat pengungkapan LKPD, ini menunjukkan menunjukkan adanya dana perimbangan dari pemerintah pusat tidak mendorong Pemda untuk melakukan pengungkapan yang labih luas. Pemerintah daerah justru lebih termotivasi dalam melakukan pengungkapan yang lebih baik ketika dana transfer atau dana perimbangan yang mereka terima rendah, sebab pemerintah daerah cenderung melakukan pengungkapan dengan lebih baik yang mengindikasikan seberapa mandiri pemerintah daerah meski dengan bantuan dana pemerintah pusat yang rendah. Hasil ini serupa dengan Lesmana (2010), Yulianingtyas (2010), Khasanah (2014), Girsang (2015), serta Prihardjanto dan Wardana (2016), tetapi berbeda dengan penelitian lain seperti Patrick (2007), Syafitri (2012), Maulana (2015), dan Hendriyani (2015).

Hasil uji hipotesis di atas menyatakan bahwa rasio kemandirian keuangan daerah berpengaruh signifikan terhadap tingkat pengungkapan LKPD. Kemandirian keuangan daerah menggambarkan kemapuan pemerintah daerah dalam membiayai sendiri kegiatan pemerintahan, pembangunan, dan pelayanan masyarakat yang telah membayar pajak dan retribusi daerah sebagai sumber pendapatan yang diperlukan daerah (Halim, 2002), oleh sebab itu pemda akan termotivasi untuk mewujudkan keinginan masyarakat sebagai principal dengan melakukan pengungkapan yang lebih baik. Hasil ini didukung oleh Lesmana (2010), namun bertolak belakang dengan fitri (2012), Maulana (2015), dan Girsang (2015). 
Pengujian hipotesis di atas menyatakan Indek Pembangunan Manusia tidak memiliki pengaruh signifikan terhadap tingkat pengugkapan LKPD. Hasil ini bertolak belakang dengan Setyowati (2016). Data menunjukkan bahwa semakin tinggi angka IPM suatu wilayah justru tidak diikuti tingginya level pengungkapan yang dilakukan pemda, ini menunjukkan yarakat sebagai principal kurang aktif berperan langsung mendorong pemerintah daerah selaku steward dalam melakukan pengungkapan yang memadai dan menyebabkan pemerintah daerah tidak termotivasi untuk meningkatkan pengungkapan dalam laporan keuangannya.

Uji hipotesis menyatakan hasil temuuan audit tahun lalu tidak berpengaruh signifikan terhadap Tingkat Pengungkapan LKPD. Sesuai dengan teori stewardship, pemerintah daerah sebagai steward seharusnya melakukan perbaikan atas berbagai temuan audit yang berkaitan dengan pengungkapan yang sesuai dengan SAP serta dikehendaki oleh principal yaitu masyarakat atau DPR sebagai wakil masyarakat dalam lingkup pemerintahan, namun Khasanah (2014) menyatakan pelaksanaan revisi, kritik, maupun rekomendasi dari BPK hanya sebatas pemenuhan kewajiban tanpa adanya hubungan langsung terhadap tingkat pengungkapan LKPD. Hasil ini didukung oleh Hilmi (2012), Andriani (2012), Khasanah (2014), Maulana (2015), Hendriyani (2015), Prihardjanto dan Wardani (2016), namun ditolak oleh Liestiani (2008).

Pengujian hipotesis di atas menyatakan hasil tingkat penyimpangan audit tahun lalu tidak berpengaruh terhadap Tingkat Pengungkapan LKPD. Meskipun tingkat penyimpangan audit telah merepresentasikan seberapa besar kerugian yang ditanggung oleh pemerintah daerah, penyimpangan audit tidak mendorong pengungkapan yang dilakukan pemda, ini memperkuat asumsi bahwa pemerintah daerah belum berkomitmen untuk meningkatkan pengungkapan dalam laporan keuangan melalui penindakan rekomendasi atas temuan kasus yang menyebabkan kerugian secara materil Pemda. Prihardjanto dan Wardani (2016) menyatakan hal tersebut terjadi disebabkan kurangnya pengawasan dari pemerintah pusat atas berbagai penyimpangan yang dilakukan pemda, sehingga rekomendasi serta koreksi oleh 
BPK sebagai upaya dalam meningkatkan pengungkapan dalam laporan keuangan belum sepenuhnya ditindaklanjuti. Hasil ini tidak didukung oleh Liestiani (2008) dan Hilmi (2012).

Pengujian hipotesis menyatakan hasil opini audit tahun lalu tidak berpengaruh terhadap Tingkat Pengungkapan LKPD. Ketika suatu pemda mendapatkan opini yang baik, pemerintah daerah cenderung akan merasa puas atau cukup atas pengungkapan yang telah dilakukan, sehingga pemda tidak termotivasi untuk melakukan pengungkapan yang lebih baik atau berkualitas atas laporan keuangannya. Hasil ini bertolak belakang dengan Andriani (2012) dan Prihardjanto serta Wardani (2016).

\section{SIMPULAN}

Berdasarkan hasil pengujian, diperoleh hasil penelitian dari tujuh variabel independen, hanya dua variabel independen yang berpengaruh secara signifikan terhadap tingkat pengungkapan laporan keuangan pemda, yaitu kekayaan dan rasio kemandirian keuangan pemerintah daera. Variabel independen lainnya, yaitu intergovernmental revenue, Indeks Pembangunan Manusia, temuan, tingkat penyimpangan, dan opini audit tidak berpengaruh signifikan terhadap tingkat pengungkapan dalam LKPD.

\section{DAFTAR PUSTAKA}

Andaiyani. (2012). Pengaruh indeks pembangunan manusia, pertumbuhan ekonomi, dan belanja operasional terhadap jumlah alokasi belanja modal pemerintahan kabupaten/kota di Propinsi Kalimantan Barat (ringkasan tesis). Diakses dari http://id.portalgaruda.org/

Andriani, E. (2012). Pengaruh Opini Audit dan Temuan Audit terhadap Tingkat Pengungkapan pada Laporan Keuangan Pemerintah daerah. Diakses dari http://lib.ui.ac.id//

Girsang, Heri AV. (2015). Analisa Faktor-Faktor yang Mempengaruhi Tingkat Pengungkapan Laporan Keuangan Pemerintah Daerah. Diponegoro journal of accounting. 4.4 1-11. Diakses dari http://ejournals1.undip.ac.id/index.php/accounting

Halim, A., Kusufi, M.S. (2014). Teori, Konsep, dan Aplikasi Akuntansi Sektor Publik (Edisi 2). Jakarta: Salemba Empat. 
Hendriyani, R. (2015). Analisis Faktor-Faktor yang Mempengaruhi Tingkat Pengungkapan Laporan Keuangan Pemerintah Propinsi di Indonesia. Diakses dari http://id.portalgaruda.org/

Hilmi, A.Z., Martani, D. (2012). Analisis Faktor-Faktor yang Mempengaruhi Tingkat Pengungkapan Laporan Keuangan Pemerintah Propinsi. Diakses dari http://id.portalgaruda.org/

Khasanah, Nur L. (2014). Pengaruh Karakteristik, Kompleksitas, dan Temuan Audit terhadap Tingkat Pengungkapan Laporan Keuangan Pemerintah Daerah. Diponegoro journal of accounting. 3. 1-11. Diakses dari http://ejournals1.undip.ac.id/index.php/accounting

Lesmana, S.I. (2010). Pengaruh Karakteristik Pemda terhadap Tingkat Pengungkapan Wajib di Indonesia. Diakses dari http://id.portalgaruda.org/

Liestiani, A., Martani, D. (2008). Local Government Financial Statement Disclosure in Indonesia. Asian Academic Accounting Association (AAAA). Diakses dari https://www.researchgate.net/publication/267560779

Maulana, C., Handayani, B. (2015). Pengaruh Karakteristik, Kompleksitas Pemerintahan dan Temuan Audit terhadap Tingkat Pengungkapan Wajib LKPD. Accounting Analysis Journal. 4. 1-11. Diakses dari http://journal.unnes.ac.id/sju/index.php/aaj

Mulyadi. (2002). Auditing Buku 1 (Edisi Enam). Jakarta: Salemba Empat.

Patrick, P.A. (2007). The Determinants of Organizational Innovativeness: A Study of GASB 34 in Pennsylvania Local Government. Diakses dari https://scholar.google.co.id/

Patton, T. K., and Bean, D. R. (2001). The why and how of the new capital asset reporting requirements. Public Budgeting and Finance. 21. 31-46.

Peraturan Pemerintah Republik Indonesia Nomor 24 Tahun 2005 Tentang Standar Akuntansi Pemerintahan.

Peraturan Pemerintah Republik Indonesia Nomor 8 Tahun 2006 Tentang Pelaporan Keuangan dan Kinerja Instansi Pemerintah.

Peraturan Pemerintah Republik Indonesia Nomor 71 Tahun 2010 Tentang Standar Akuntansi Pemerintahan.

Peraturan Menteri Dalam Negeri Nomor 13 Tahun 2006 Tentang Pedoman Pengelolaan Keuangan Daerah.

Priharjanto, A., Wardani, Y.Y. (2016). Pengaruh Temuan, Tingkat Penyimpangan, Opini Audit, dan Karakteristik Pemerintah Daerah terhadap Tingkat Pengungkapan laporan Keuangan Pemerintah Provinsi di Indonesia. Diakses dari http://jurnal.pknstan.ac.id/index.php/JIA/article/view/72/62

Raharjo, Eko. 2007. Teori Agensi dan Teori Stewardship dalam Perspektif Akuntansi. Fokus Ekonomi. Vol. 2 No. 1 Juni 2007. Diakses dari google.com

Syafitri, F., Setyaningrum, D. (2012). Analisis Pengaruh Karakteristik Pemerintah Daerah terhadap Tingkat Pengungkapan Laporan Keuangan. Jurnal Akuntansi dan Keuangan Indonesia. 9. 154-170. Diakses dari http://lib.ui.ac.id/

Setyowati, L. (2016). Determinan yang Mempengaruhi Pengungkapan Laporan Keuangan Pemerintah Daerah. Jurnal Bisnis dan Manajemen. 6. 45-62. Diakses dari http://id.portalgaruda.org/ 
Suhardjanto, D., Rusmin, Mandasari, P., dan Brown, A. (2010). Mandatory Disclosure Compliance and Local Government Characteristics: Evidence from Indonesian Municipalities. Working Paper Series.

Undang-Undang Nomor 22 Tahun 1999 Tentang Pemerintah Daerah.

Undang-Undang Nomor 25 Tahun 1999 Tentang Perimbangan Keuangan antara Pemerintah Pusat dan Pemerintah Daerah.

Undang-Undang Nomor 17 Tahun 2003 Tentang Keuangan Negara.

Undang-Undang Nomor 15 Tahun 2004 Tentang Pemeriksaan Pengelolaan dan Tanggung Jawab Keuangan Negara.

Undang-Undang Nomor 32 Tahun 2004 Tentang Pemerintahan Daerah.

Yulianingtyas, R., Suhardjanto, D. (2010). Pengaruh Karakteristik Pemerintah Daerah Terhadap Kepatuhan Pengungkapan Wajib Dalam Laporan Keuangan Pemerintah Daerah. Diakses dari http://id.portalgaruda.org/ 